\title{
EFFECTS OF KEY ENGINEERING SOIL PARAMETERS ON THE SURFACE OF PIPELINE STEEL UNDER DIFFERENT ENVIRONMENTAL EXPOSURES
}

\section{KHOTSO KHOELE and DAVID JAMES DELPORT}

Department of Chemical, Metallurgical

and Materials Engineering

Tshwane University of Technology

Pretoria

South-Africa

e-mail: Khotsokhoele@gmail.com

\begin{abstract}
Pipeline steel (PS) electrodes were buried in seven different soil samples (SSs), and they characterized by weight loss (WL), scanning electron microscopy (SEM), energy dispersive X-ray (EDX), and X-ray diffraction (XRD). WL measurements confirmed previous electrochemical measurements in terms of excessive corrosion rates under acidic media (SS 4). The SEM/EDX analysis also revealed a severe ulcerous corrosion attack on the entire surface of the electrode in SS 4. In fact, the retrieved steel surface was covered by a black layer of corrosion products; and the XRD analysis on corrosion products encompassed iron phases: goethite, hematite, and ferryhidrite. These oxides are the habitats of most acidic soils, and cause re-acidification of the soils during hot climatic conditions. Overall, analysis showed that the corrosion of buried PSs differ from environment to environment, and the corrosion rates more closely related to $\mathrm{pH}$ and soil resistivity. Distinctively, corrosion rates were least under neutral environment (soil with $\mathrm{pH}$ 7.7) and higher in soil with $\mathrm{pH}$ value of 3.1.
\end{abstract}

Keywords and phrases: corrosion, environment, steel, pipelines, soil.

Received January 23, 2017

(C) 2017 Scientific Advances Publishers 


\section{Introduction}

Corrosion of buried pipeline steels (PSs) remains as an ongoing phenomenon [1] regardless of the synergistic protection offered by coating and cathodic protection (CP) [2,3]. This problem is deemed to arise from the soil instabilities which amongst other factors include groundwater. When the groundwater is in contact with the pipeline, it causes corrosion [4, 5-7]. There are notably six critical soil parameters which determine severity of corrosion on buried PSs [8]. Most of these parameters have thoroughly been studied by numerous researchers [9-11], and they include; $\mathrm{pH}$, moisture, sulphate and chloride contents, electrical resistivity, redox potential, and microbes. Amongst these soil parameters, the $\mathrm{pH}$, moisture, and electrical resistivity remained the most troublesome in accentuation of corrosion on buried PSs. Soil resistivity actually decreases with an increment in water content and the concentration of ionic species in the soil [12-14], while low $\mathrm{pH}$ (acidic $\mathrm{pH}$ below 4) pose a severe corrosion attack on buried PSs due to their effects on the solubility layer of corrosion products [15].

During corrosion processes, different iron oxides form on the surface of buried PSs. These oxides are dictated by the soil properties of each soil, and they are very influential on buried PSs under certain environments, particularly, red clay soils. Red clay soils could form oxides which could be reducible under deaerated conditions, and accelerate corrosion rates during their actions when they act as cathodic depolarizers [16].

From our previous published work, we focus extensively on soil corrosion in terms of physicochemical properties possessed from each soil, and now the present paper reveals effects of key engineering soil properties on the surface of buried PS from seven SSs where corrosion previously occurred in order to scrutinize phases or minerals of iron oxides which could negatively depolarise the cathodic reaction to cause higher corrosion rates on buried PSs. 


\section{Materials and Methods}

\subsection{Materials}

\subsubsection{Soil characterization}

Soil samples (SSs) were collected from seven representative sites. The samples were collected at the depth of about $0.725 \mathrm{~m}$, placed in polyethylene bags and taken to the laboratory. The samples were characterized as received: air dried at $105^{\circ} \mathrm{C}$, cooled at room temperature and finally sieved. The soil-extract solution (SES) was prepared by extracting the soil solution with the water-soil ratio of $1: 1$ for chemical compositions determination. The analyses were attained by ion chromatography and inductively coupled plasma. JENWAY $3510 \mathrm{pH}$ meter was also used to determine the $\mathrm{pH}$ of the soils. While the organic matter content and \% moisture was obtained through the utilization of an oven by dry combustion method and gravimetric method, respectively.

\subsubsection{Chemical composition}

The subject material in this research was low carbon steel panel which represents the exact pipeline which is being used in the field for water distribution, and it was analysed with spark ignition spectroscopy. The compositions were obtained as follows: $98.06 \% \mathrm{Fe}, 0.09 \% \mathrm{C}, 1.53 \% \mathrm{Mn}$, $0.29 \% \mathrm{Si}, 0.013 \% \mathrm{P}, 0.002 \% \mathrm{~S}$, and $0.02 \% \mathrm{~V}$.

\subsubsection{Preparation of the specimen}

Firstly, the specimen were cut to $2 \mathrm{~cm}^{2}$. Then an insulated copper wire was attached onto each sample's surface using an aluminium conducting tape, and the samples were cold mounted in epoxy mixed with resin. Secondly, the coupons were ground by 240, 400, 600, 800, 1000, and 1200 grit sand papers, and the working area of $1 \mathrm{~cm}^{2}$ was left. Thirdly, the samples were polished to a mirror like shapes, rinsed in distilled water and acetone to remove residual surface water. The cleaning operation was performed quickly to avoid premature corrosion. 


\subsection{Weight loss measurements}

The weight loss (WL) on each LCS electrode was measured weekly utilizing the weigh balance, and the difference (WL) was calculated based on the difference between weight of each electrode before and after the burial.

\subsection{Scanning electron microscopy (SEM) analysis}

High resolution scanning electron microscope (JSM-7600F) equipped with a field emission cathode and coupled to an EDX (INCA) was used to characterize LCS electrodes which were buried in the soils. The SEM was used to characterize the surface morphologies, while EDX was for quantitative elemental analyses through INCA software. Prior to characterization, all steel samples were carbon coated in order to make conductive surface.

\subsection{X-ray diffraction (XRD) analysis}

XRD was utilised to identify various minerals and phases that were formed on the PS electrodes and corrosion products after the measurements. The X"Pert PRO Diffractometer by PAN analytical was

utilized, and was operated with goniometer $2 \theta$ values ranging from $0^{\circ}$ to $100^{\circ}$. The constituent minerals were compared to diffraction patterns in the database in order to identify them.

\section{Results}

\subsection{Weight loss measurements}

Table 1 shows soil parameters obtained from some of included measurements, while Figure 1 shows WL measurements from LCS electrodes, in terms of $\mathrm{pH}$ obtained in each soil corresponding to Table 1, buried three months in soils. From the observation in Table 1, amongst other things shown, it can be seen that SS 4 had low $\mathrm{pH}$ and low electrical resistivity which are major indicative of aggressive corrosive conditions in soils. Clearly then, in Figure 1, it can be seen that LCS electrode which was buried in SS 4 rapidly lost the weight, and this evidently corroborates to higher corrosion rates in that soil. 
Table 1. Chemical composition of as received soil samples in the laboratory

\begin{tabular}{|c|c|c|c|c|c|c|c|c|c|c|c|}
\hline \multirow{2}{*}{$\begin{array}{c}\text { Soil } \\
\text { Sample } \\
\text { (SS) }\end{array}$} & \multirow[t]{2}{*}{$\mathrm{pH}$} & \multicolumn{7}{|c|}{ Chemical composition (mg/l) } & \multirow{2}{*}{$\begin{array}{c}\% \\
\text { Moisture }\end{array}$} & \multirow{2}{*}{$\begin{array}{c}\text { Organic } \\
\text { matter } \\
\text { content } \\
(\%)\end{array}$} & \multirow{2}{*}{$\begin{array}{l}\text { Resistivity } \\
\text { in } \Omega \mathrm{cm}\end{array}$} \\
\hline & & $\mathrm{Cl}^{-}$ & $\mathrm{SO}_{4}^{-}$ & $\mathrm{Ca}^{2+}$ & $\mathrm{Mg}^{2+}$ & $\mathrm{K}^{+}$ & $\mathrm{Na}^{+}$ & $\mathrm{Fl}^{-}$ & & & \\
\hline 1 & 5.5 & 261.5 & 1039 & 240 & 13 & 490 & 60 & 5.3 & 6 & 9.7 & 2259.8 \\
\hline 2 & 7.7 & 181 & 597 & 3.2 & 6.6 & 7.8 & 631 & 4.9 & 3.9 & 16.5 & 32727.3 \\
\hline 3 & 5.7 & 113.5 & 3282.5 & 450 & 17 & 25 & 130 & 4.9 & 3.3 & 11 & 23804.4 \\
\hline 4 & 3.1 & 2804.5 & 12082 & 75 & 5.1 & 750 & 15 & 5.2 & 12 & 8 & 1818.16 \\
\hline 5 & 5.62 & 1899.1 & 896.2 & 156 & 10.3 & 321 & 53 & 6.4 & 10 & 7.8 & 2345.5 \\
\hline 6 & 6.3 & 355.5 & 5001.8 & 53 & 89 & 155 & 19 & 5.5 & 8.0 & 11.6 & 3986.01 \\
\hline 7 & 5.8 & 195.6 & 4663.2 & 82 & 7.9 & 63 & 42 & 6.3 & 6.2 & 10.4 & 4066.1 \\
\hline
\end{tabular}




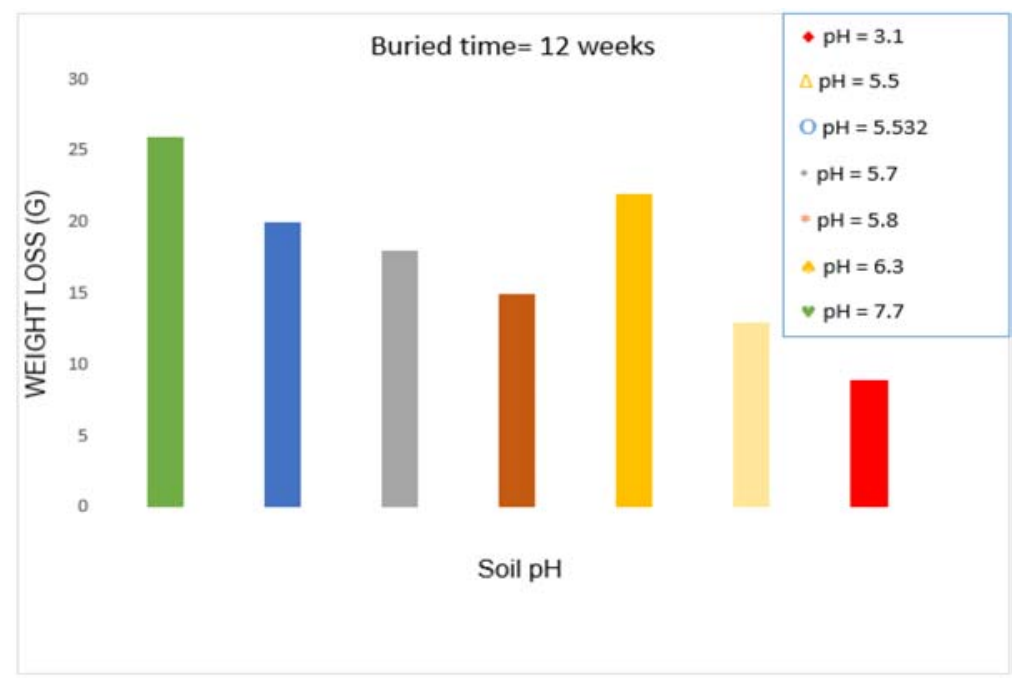

Figure 1. Weight loss measurements on bare electrodes in different soils.

\subsection{Surface morphologies}

Figures 2 and 3 show morphologies of bare electrodes buried in different soils for three months and corresponding EDX, respectively. In Figure 2(a) and (b), a porous-white sport layers of corrosion products are observed, and are composed of iron [16]. Slightly similar morphology is also observed in Figure 2(c) with corrosion products (iron oxides) in a form of flower-like structures. While Figure 2(d) and (e) showed black corrosion product layers (probably magnetite) covering the grinding grooves of LCS electrodes. Figure 2(f) on the other hand shows the surface consisting primarily cementite $\left(\mathrm{Fe}_{3} \mathrm{C}\right)$, which is a part of a relative stable microstructure of LCS. Based on Akbarzadeh et al. [18] discovery, cementite is accumulated on the surface after preferential dissolution of the active ferrite phase, and actually provide an area for cathodic reactions and that consequent to galvanic coupling with ferrite [19]. In most cases, the ferrite-pearlite structures are normal during corrosion of bare LCS. In fact, the ferrite corrodes preferentially and the corrosion products thereafter deposit on top of them [18]. Distinctively, Figure 2(g) shows morphology with a severe ulcerous corrosion attack on 
the entire surface of electrode. In fact, the retrieved steel surface was covered by a black layer corrosion product (magnetite). The similar results were also obtained by Yan et al. [19, 20], and that shows an occurred rapid corrosion attack on the electrode.

Figure 3 shows corresponding EDX analysis on LCS buried in soils. From Figure 3(a) to 3(g), it can be seen that the highest peaks are of iron $(\mathrm{Fe})$ and oxygen (O). Comparing to Figure 2, these conditions indicate that corrosion has occurred under all burial conditions. In fact, as evidenced by elemental analysis which encompass more oxygen $(\mathrm{O})$ and iron $(\mathrm{Fe})$ as higher elements in Figure 3, these effects are attributed to partially and momentarily protective occurrence provided by corrosion products in a form of $\mathrm{FeO}, \mathrm{Fe}_{2} \mathrm{O}_{3}$ or $\mathrm{Fe}_{3} \mathrm{O}_{4}$ [17]. Furthermore, there is also a notable amount of sulphur in Figure 3(b), (d), (f) and (g). Sulphur in anaerobic conditions could be converted to sulphide by sulphur reducing bacteria (SRB). So, if one of the soil environments is anaerobic, higher corrosion rates could happen due to their effects as cathodic depolarizers [21]. 

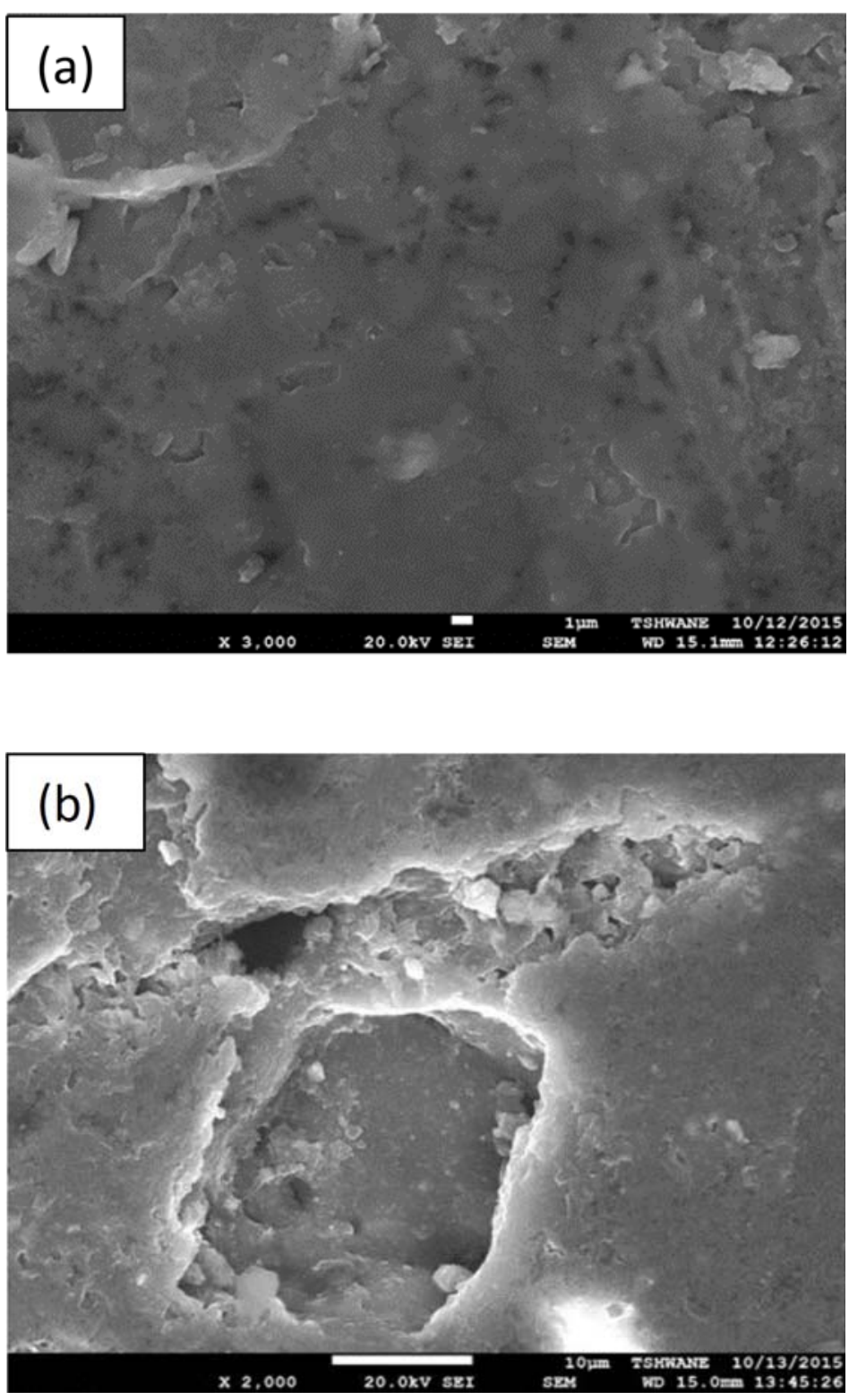

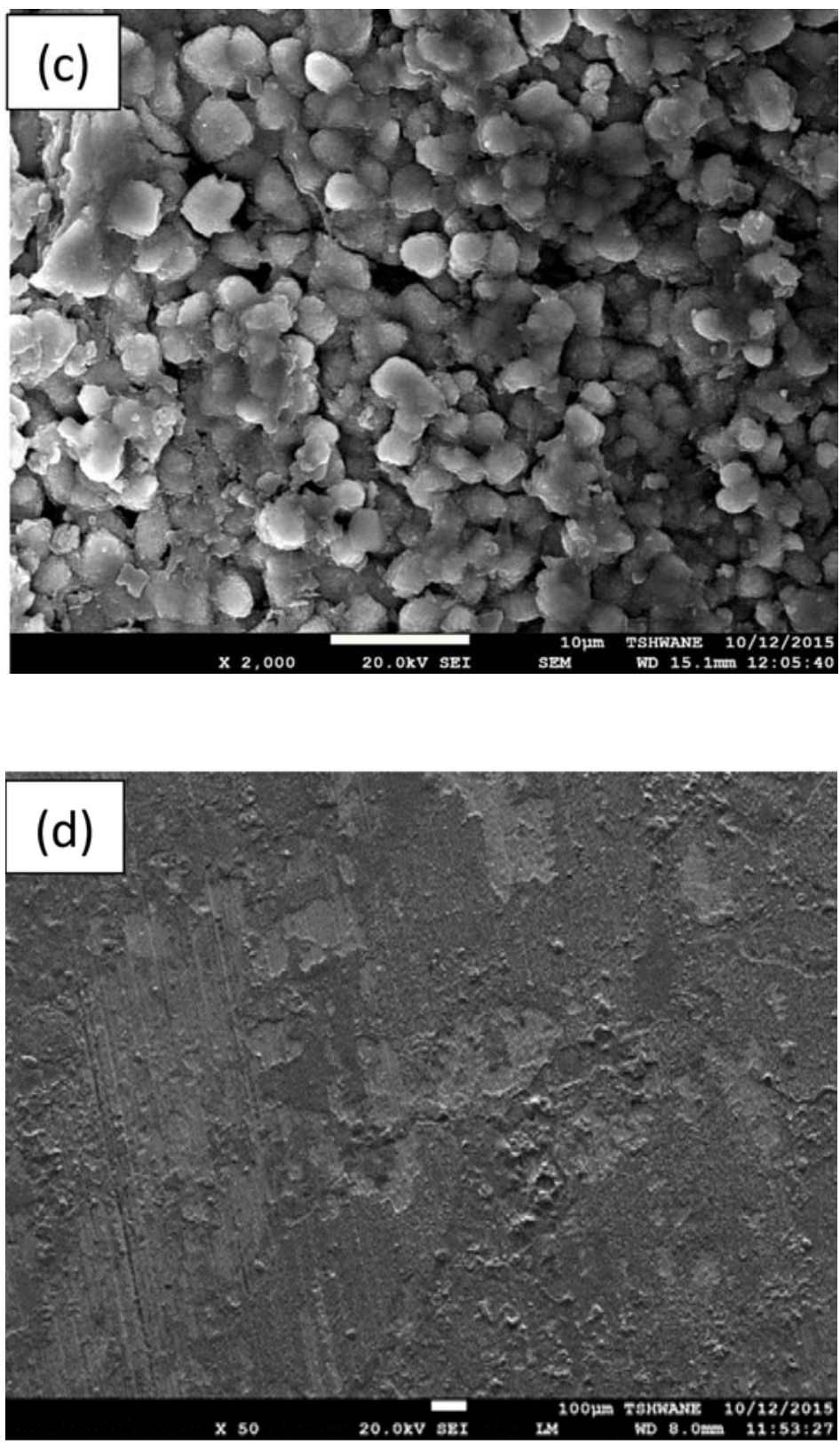

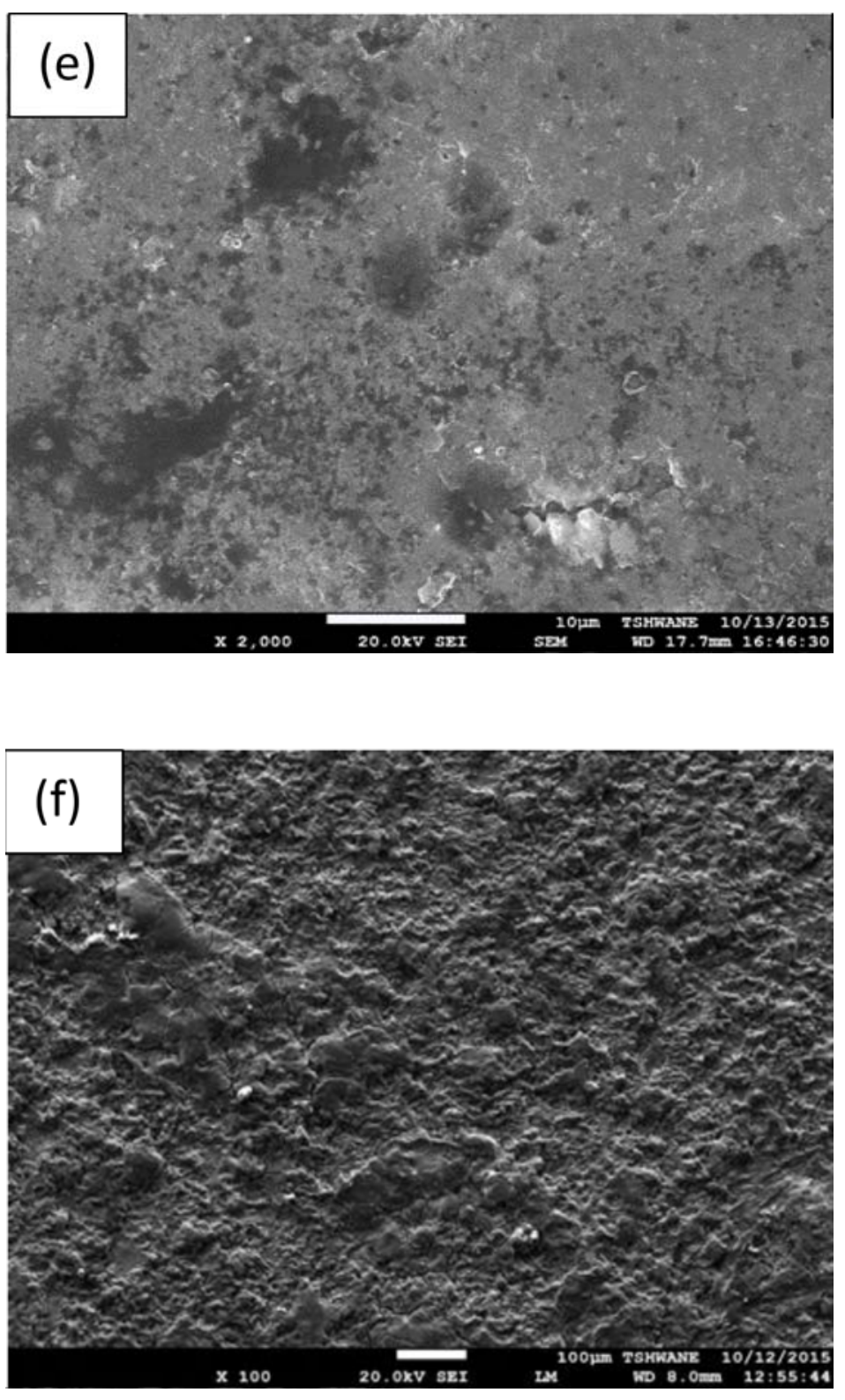


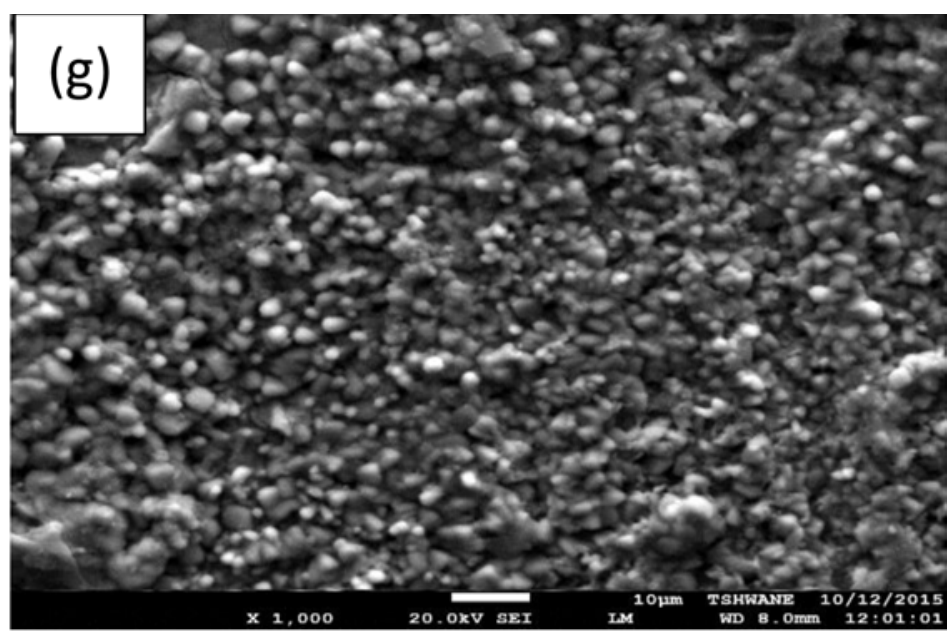

Figure 2. Surface morphologies of PS electrodes buried in different soil pH: (a) $\mathrm{pH} 7.7$, (b) $\mathrm{pH} 6.3$, (c) $\mathrm{pH} 5.8$, (d) $\mathrm{pH} 5.7$, (e) $\mathrm{pH} 5.62$, (f) $\mathrm{pH} 5.5$, and (g) $\mathrm{pH} 3.1$. 

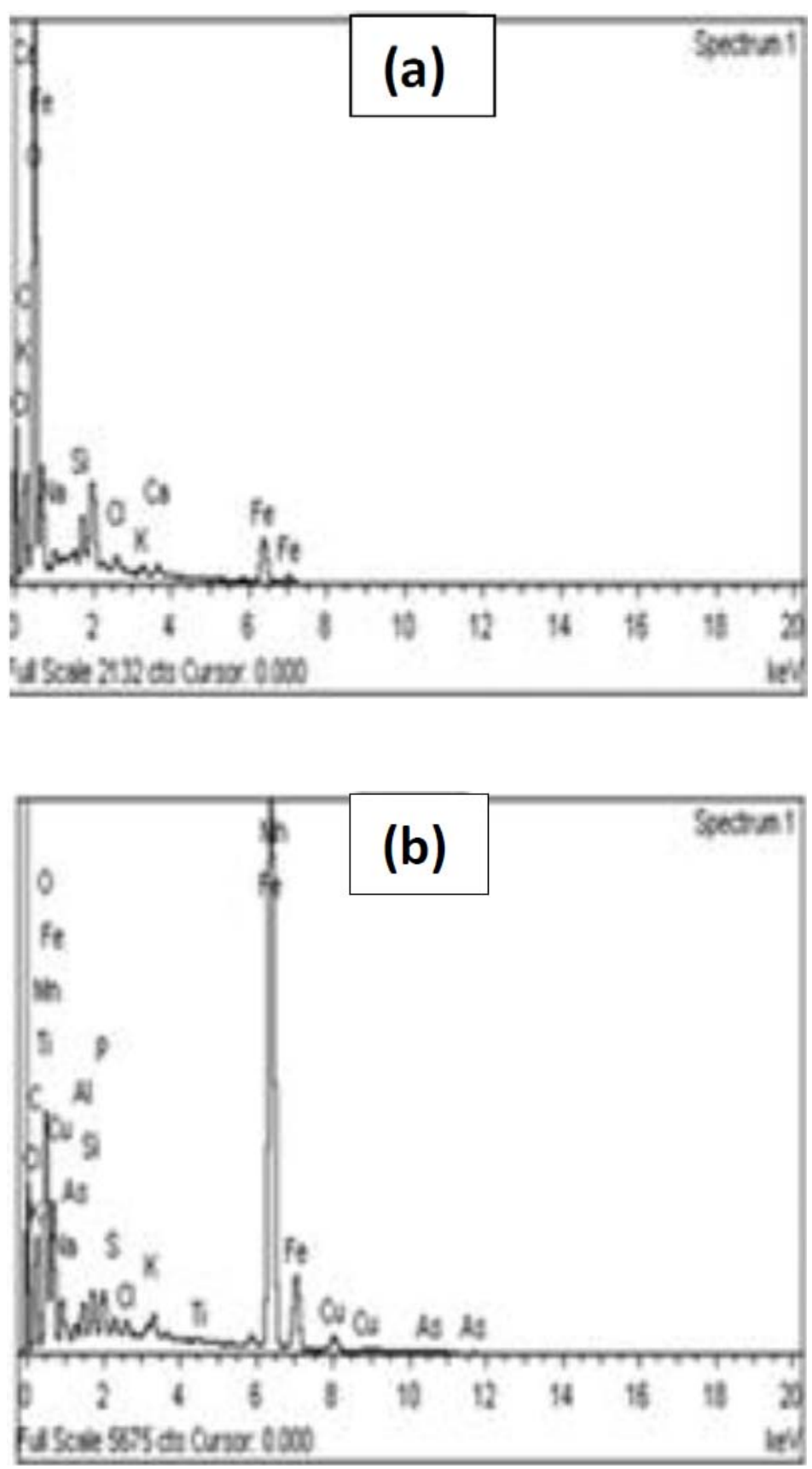

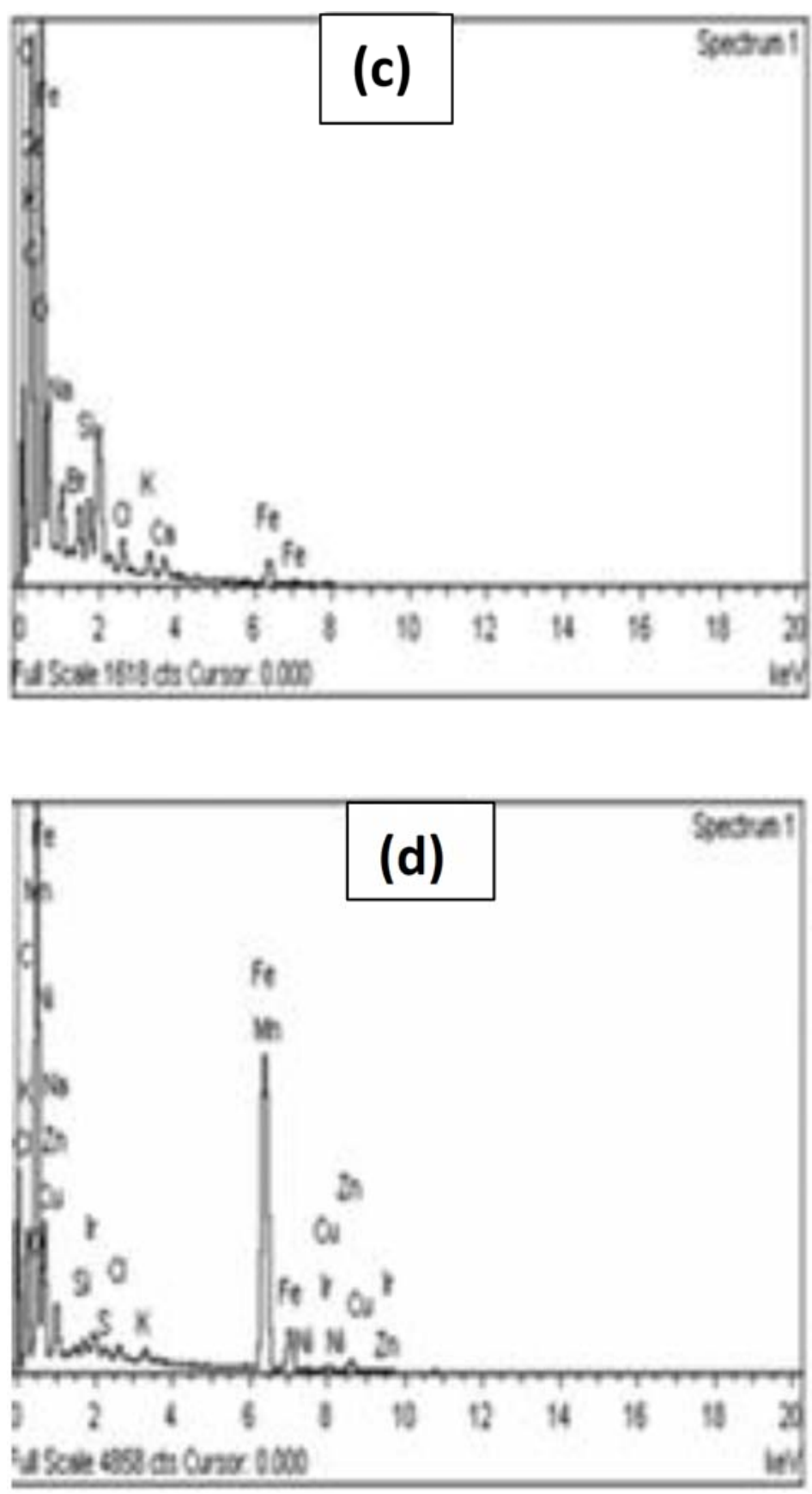

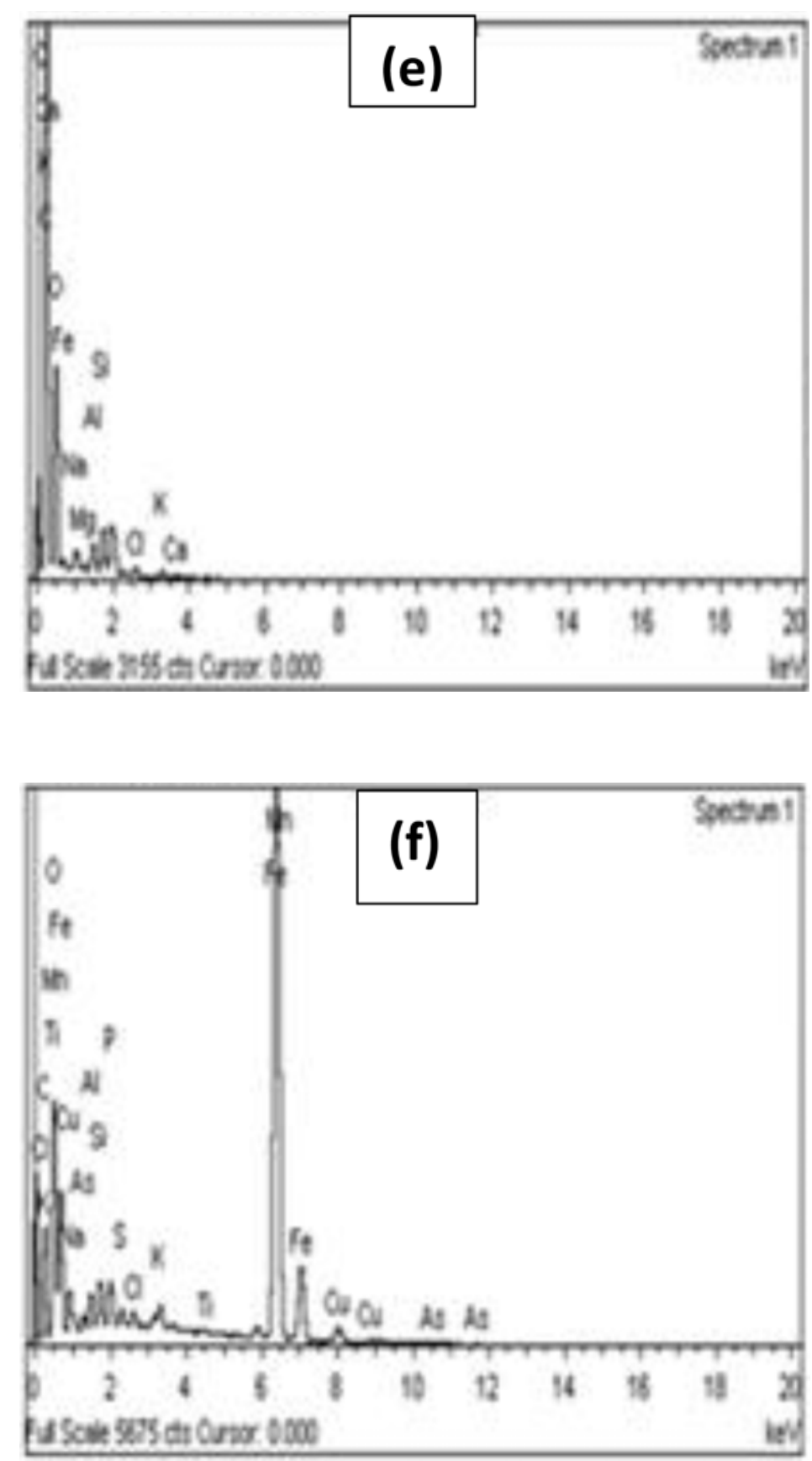


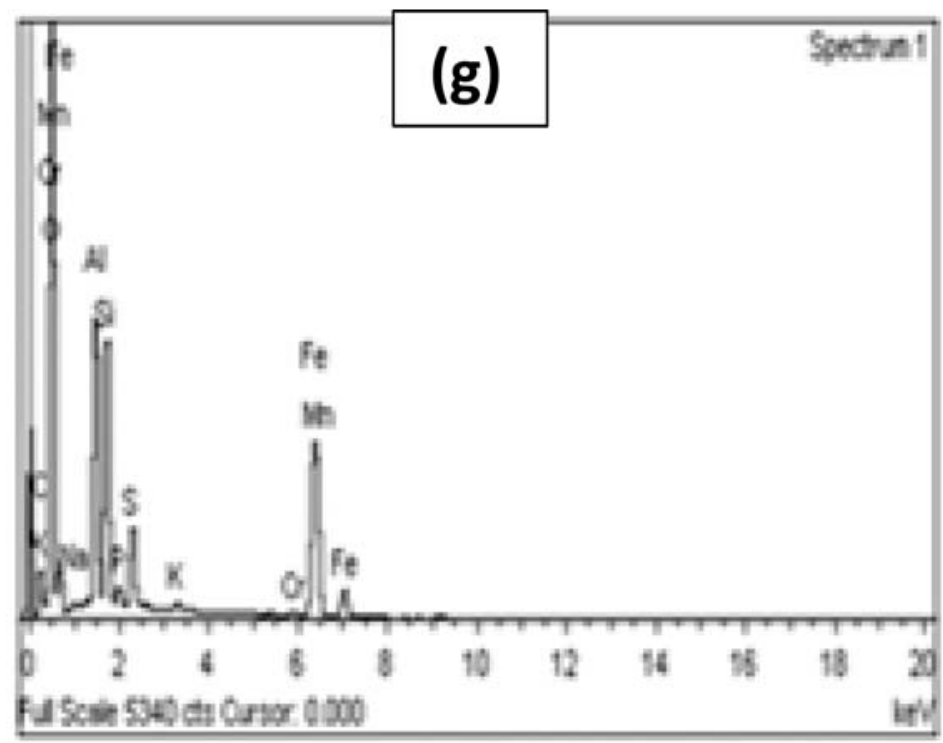

Figure 3. EDX analysis of LCS electrodes buried in different soil $\mathrm{pH}$ : (a) $\mathrm{pH} 7.7$, (b) $\mathrm{pH} 6.3$, (c) $\mathrm{pH} 5.8$, (d) $\mathrm{pH} 5.7$, (e) $\mathrm{pH} 5.62$, (f) $\mathrm{pH} 5.5$, and (g) $\mathrm{pH} 3.1$.

\subsection{Phase identification}

Figure 4 reveals phases identified from corrosion products of LCS electrode which was buried is SS 4. The phases show four different oxides consisting iron: goethite, hematite, magnetite, and ferryhidrite as can be seen in Figure 4. These oxides occur when iron is in contact with acidic environment, and they are generally associated with corrosion of steel. In fact, the combination of hematite and goethite, in most cases are the habitat of acidic soil, and causes re-acidification of the soil during hot climatic conditions. These observations reinforce the literature and previous findings $[19,20]$. 


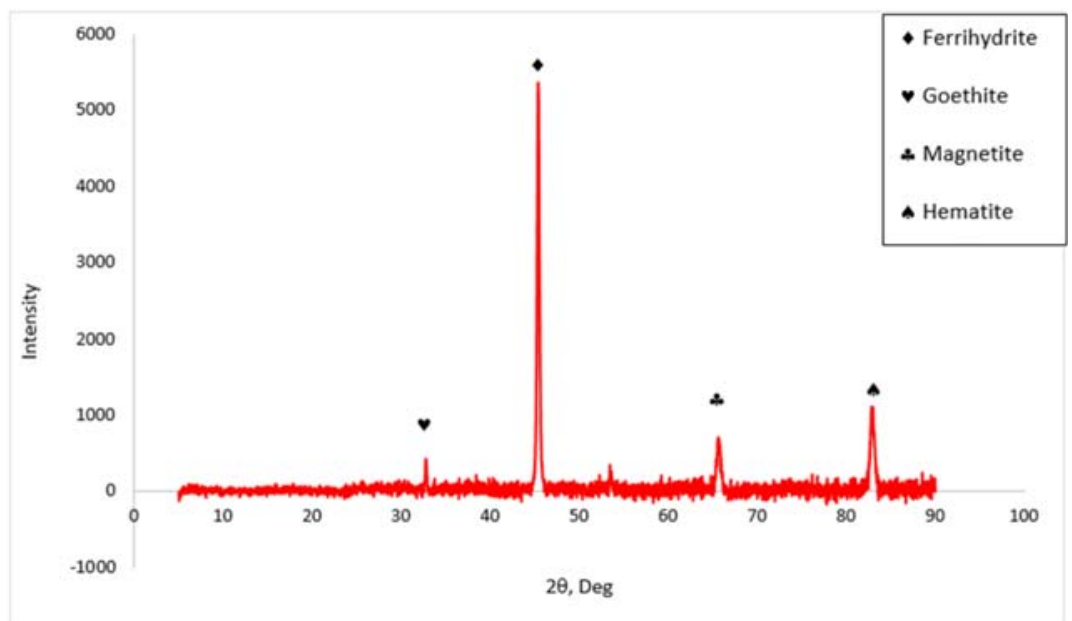

Figure 4. XRD phase analysis on bare pipeline steel buried in soil pH 3.1.

\section{Discussion}

Low $\mathrm{pH}$ and high moisture content on soils are generally considered to be the most determinants of the soil corrosivity. The results demonstrated in Figure 1 reinforces the literature as the highest weight loss measurement is seen on the specimen buried under acidic media ( $\mathrm{pH}$ 3.1) [22]. The soils, in most cases, become increasingly acidic due to leaching of basic cations: $\mathrm{Ca}^{2+}, \mathrm{Mg}^{2+}, \mathrm{Na}^{+}$, and $\mathrm{K}^{+}$. In addition, as the SS 4 was sampled next to mine dump, the acidic nature might be stemming from cyanide and sulphuric acid media which are normally used to leach gold from its ore. Eventually, this soil becomes more troublesome on corrosion products, and this causes a redox active of corrosion products $\left(\mathrm{Fe}_{2} \mathrm{O}_{3}\right.$ and $\left.\mathrm{FeOOH}\right)$. The goethite $(\mathrm{FeOOH})$, particularly, directly engage in the cathodic reaction to reduce ferrous iron $\left(\mathrm{Fe}^{2+}\right)$ as evidenced on the following reactions: 


\section{Anodic reaction:}

$$
\mathrm{Fe} \rightarrow \mathrm{Fe}^{2+}+2 \mathrm{e}^{-}(\mathrm{Fe} \text { dissolution })
$$

\section{Cathodic reaction:}

$$
8 \mathrm{FeOOH}+\mathrm{Fe}^{2+}+2 \mathrm{e}^{-} \rightarrow 3 \mathrm{Fe}_{3} \mathrm{O}_{4}+4 \mathrm{H}_{2} \mathrm{O}
$$

Overall and based on observations and the literature, the highly corrosive environment is proved to be $\mathrm{SS} 4$ ( $\mathrm{pH} 3.1$ ) [22].

\section{Conclusion}

Low carbon steel electrodes used in this work were bare (uncoated substrates), and the corrosion products formed under different soil exposures have thoroughly been characterized. The weight loss, scanning electron microscopy, and X-ray diffraction analysis are present. The scanning electron microscopy analysis on the surface pipeline steel prior to any corrosion measurement revealed the main constituent elements as: iron $(\mathrm{Fe})$, carbon $(\mathrm{C})$, and copper $(\mathrm{Cu})$. The energy dispersive X-ray analyses revealed corrosion products with higher oxygen and iron content in all samples, and that shows corrosion occurrence under all media. Furthermore, the scanning electron microscopy morphologies revealed various distinctions after corrosion measurements. Furthermore, the $\mathrm{X}$-ray diffraction analysis revealed the presence of complex phases: goethite and hematite from steel electrode buried in soil sample 4. From the results overall, SS 4 proved to be the most troublesome soil in contact with buried low carbon pipeline. In fact, the weight loss and surface morphologies corroborate to earlier findings from electrochemical measurements and other physicochemical properties in previous published work.

\section{Acknowledgement}

Thanks are due to the following individuals and their respective departments for their kind permission in supporting this study with the information and guidance: Dr Apata Olubambi, Mr Armin Schwab and Dr Andrew Anthony. Over and above, special thanks are given to 
Corrosion Institute of Southern Africa (CorriSA) for creating platform for networking and exchanging of ideas amongst corrosionists, engineers, consultants, and academics. I would also like to thank Tshwane University of Technology, particularly, the Department of Chemical, Metallurgical and Materials Engineering for giving me the opportunity to study my Master's.

\section{References}

[1] K. W. Hameed, A. S. Yarob and A. A. Khadom, Mathematical model for cathodic protection in a steel-saline water system, Journal of Taibah University for Science (2015), 1-6.

[2] J. T. Zhang, J. M. Hu, J. Q. Zhang and C. N. Cao, Studies of impedance models and water transport behaviors of polypropylene coated metals in $\mathrm{NaCl}$ solution, Progress in Organic Coatings 49 (2004), 293-301.

[3] B. M. Fernández-Pérez, J. A. González-Guzmán, S. González and R. M. Souto, Electrochemical impedance spectroscopy investigation of the corrosion resistance of a waterborne acrylic coating containing active electrochemical pigments for the protection of carbon steel, Int. J. Electrochem. Sci. 9 (2014), 2067-2079.

[4] X. Wang, C. Wang, X. Tang and Z. Guo, A comparison of cathodic protection parameters with high-strength pipeline steels in soil solution, Int. J. Electrochem. Sci. 9 (2014), 8199-8210.

[5] M. Barbalat, L. Lanarde, D. Caron, M. Meyer, J. Vittonato, F. Castillon, S. Fontaine and P. Refait, Electrochemical study of the corrosion rate of carbon steel in soil: Evolution with time and determination of residual corrosion rates under cathodic protection, Corrosion Science 55 (2012), 246-253.

[6] M. Yan, C. Sun, J. Xu and W. Ke, Electrochemical behavior of API X80 steel in acidic soils from Southeast China, Int. J. Electrochem. Sci. 10 (2015), 1762-1776.

[7] S. R. A. Saupi, M. A. Sulaiman and M. N. Masri, Effects of soil properties to corrosion of underground pipelines: A review, J. Trop. Resour. Sustain. Sci. 3 (2015), 14-18.

[8] A. M. El-Shamy, M. F. Shehata and A. I. M. Ismail, Effect of moisture contents of bentonitic clay on the corrosion behavior of steel pipelines. Applied Clay Science 114 (2015), 461-466.

[9] D. Nguyen Dang, L. Lanarde, M. Jeannin, R. Sabot and P. Refait, Influence of soil moisture on the residual corrosion rates of buried carbon steel structures under cathodic protection, Electrochimica Acta 176 (2015), 1410-1419. 
[10] I. S. Cole and D. Marney, The science of pipe corrosion: A review of the literature on the corrosion of ferrous metals in soils, Corrosion Science 56 (2012), 5-16.

[11] E. E. Oguzie, I. B. Agochukwu and A. I. Onuchukwu, Monitoring the corrosion susceptibility of mild steel in varied soil textures by corrosion product count technique, Materials Chemistry and Physics 84 (2004), 1-6.

[12] A. S. Ikechukwu, N. H. Ugochukwu, R. A. Ejimofor and E. Obioma, Correlation between soil properties and external corrosion growth rate of carbon steel, The International Journal of Engineering and Science (IJES) 03 (2014), 38-47.

[13] Y. H. Wu, T. M. Liu, S. X. Luo and C. Sun, Corrosion characteristics of Q235 steel in simulated Yingtan soil solutions, Mat.-Wiss. U. Werkstofftech. 41 (2010), 142-146.

[14] Fanrong Zeng, Shafaqat Ali, Haitao Zhang, Younan Ouyang, Boyin Qiu, Feibo Wu and G. Zhang, The influence of $\mathrm{pH}$ and organic matter content in paddy soil on heavy metal availability and their uptake by rice plants, Environmental Pollution 159 (2011), 84-91.

[15] S. Nešic, Key issues related to modelling of internal corrosion of oil and gas pipelines - A review, Corrosion Science 49 (2007), 4308-4338.

[16] M. Yan, C. Sun, J. Xu, J. Dong and W. Ke, Role of Fe oxides in corrosion of pipeline steel in a red clay soil, Corrosion Science 80 (2014), 309-317.

[17] A. Cervantes-Tobón, J. G. Godínez-Salcedo, J. L. González-Velázquez and M. DíazCruz, corrosion Rates of API 5L X-52 and X-65 steels in synthetic brines and brines with $\mathrm{H}_{2} \mathrm{~S}$ as a function of rate in a rotating cylinder electrode, Int. J. Electrochem. Sci. 9 (2014), 2454-2469.

[18] E. Akbarzadeh, I. M. N. Mohamad and A. A. Rahim, Corrosion inhibition of mild steel in near neutral solution by kraft and soda lignins extracted from oil palm empty fruit bunch, Int. J. Electrochem. Sci. 6 (2011), 5396-5416.

[19] M. Yan, C. Sun, J. Xu, T. Wu, S. Yang and W. Ke, Stress corrosion of pipeline steel under occluded coating disbondment in a red soil environment, Corrosion Science 93 (2015), 27-38.

[20] M. Yan, C. Sun, J. Xu and W. Ke, Electrochemical behavior of API X80 steel in acidic soils from Southeast China, Int. J. Electrochem. Sci. 10 (2015), 1762-1776.

[21] B. N. Popov and S. P. Kumaraguru, 25- Cathodic Protection of Pipelines, in: M. Kutz (Ed.) Handbook of Environmental Degradation of Materials (Second Edition), William Andrew Publishing, Oxford, 2012, pp. 771-798.

[22] A. I. M. Ismail and A. M. El-Shamy, Engineering behaviour of soil materials on the corrosion of mild steel, Applied Clay Science 42 (2009), 356-362. 